Grand Valley State University

ScholarWorks@GVSU

$3-2015$

\title{
Tackling Wicked Food Issues: Applying the Wicked Problems Approach in Higher Education to Promote Healthy Eating Habits in American School Children
}

Ann Marie Fauvel

Grand Valley State University, fauvela@gvsu.edu

Danielle L. Lake

Grand Valley State University, dlake@elon.edu

Follow this and additional works at: https://scholarworks.gvsu.edu/lib_articles

\section{ScholarWorks Citation}

Fauvel, Ann Marie and Lake, Danielle L., "Tackling Wicked Food Issues: Applying the Wicked Problems Approach in Higher Education to Promote Healthy Eating Habits in American School Children" (2015). Faculty Peer Reviewed Articles. 6.

https://scholarworks.gvsu.edu/lib_articles/6

This Article is brought to you for free and open access by the Liberal Studies at ScholarWorks@GVSU. It has been accepted for inclusion in Faculty Peer Reviewed Articles by an authorized administrator of ScholarWorks@GVSU. For more information, please contact scholarworks@gvsu.edu. 


\section{Food Studies}

An Interdisciplinary Journal

\section{Tackling Wicked Food Issues}

Applying the Wicked Problems Approach in Higher Education to Promote Healthy Eating Habits in American School Children 
FOOD STUDIES: AN INTERDISCIPLINARY JOURNAL

www.food-studies.com

First published in 2015 in Champaign, Illinois, USA

by Common Ground Publishing LLC

www.commongroundpublishing.com

\section{ISSN: $2160-1933$}

C 2015 (individual papers), the author(s)

(C) 2015 (selection and editorial matter) Common Ground

All rights reserved. Apart from fair dealing for the purposes of study, research, criticism or review as permitted under the applicable copyright legislation, no part of this work may be reproduced by any process without written permission from the publisher. For permissions and other inquiries, please contact cg-support@commongroundpublishing.com.

Food Studies: An Interdisciplinary Journal is

peer-reviewed, supported by rigorous processes of criterionreferenced article ranking and qualitative commentary,

ensuring that only intellectual work of the greatest substance and highest significance is published. 


\title{
Tackling Wicked Food Issues: Applying the Wicked Problems Approach in Higher Education to Promote Healthy Eating Habits in American School Children
}

\author{
Danielle Lake, Grand Valley State University, United States \\ Anne Marie Fauvel, Grand Valley State University, United States
}

\begin{abstract}
Life-long healthy eating habits linked with sustainable local agricultural practices, as "wicked problems" in the United States, are intractable, on-going, and high-stakes issues. An interdisciplinary university course was developed to engage students in participatory research and fieldwork on the inextricably linked dimensions of food, health, and sustainability. Students worked with community partners, stakeholders, and experts to address the specific interdisciplinary issues of diet and promotion of healthy eating habits in American school children. Using a "bottom-up" approach, students co-developed projects with stakeholders (including school children) to empower movement for change. This interactive research process created an iterative feedback loop which fostered more inclusive and creative projects to meliorate the wicked problem at hand. Project proposals ranged from the creation of an interactive website intended for school children, to field trips to local farming communities, to "how-to" workshops for gardening and meal planning, to local tastings. Projects were, in the end, shared with and vetted by community partners for future coimplementation. Using food as an interdisciplinary agent to bring collaboration to fruition, the results of this work indicate higher education could be more effective in preparing students for our 21st century food challenges by developing experiential learning courses in partnership with food communities.
\end{abstract}

Keywords: Wicked Problems, Food Issues, Children, Health, Experiential Learning, Soft Systems Thinking

\section{Introduction}

$\mathrm{L}$

ife-long healthy eating habits and sustainable local agricultural practices, as "wicked problems" in America, are intractable, on-going and high-stakes issues. With these issues in mind, an interdisciplinary university course, entitled "Wicked Problems of Sustainability," was developed to engage students in participatory research and fieldwork on the inextricably linked dimensions of food, health, and sustainability. Students work with community partners, stakeholders and experts to address the specific interdisciplinary "wicked" issue of eating habits in American school children. Employing a bottom-up approach, students codevelop projects with stakeholders. We argue this interactive research process created an iterative feedback loop which fostered more inclusive and creative projects to meliorate the wicked problem at hand. Project proposals ranged from the creation of an interactive website intended for school children, to field trips to local farming communities, to "How-To" workshops for gardening and meal planning, to local tastings. Using food as an interdisciplinary agent to bring collaboration to fruition, we contend universities could be more effective in preparing students for the 21 st century by developing more courses with the community's needs in mind.

\section{Wicked Problems}

Many of our public problems today - problems like poverty, pollution, and food insecurity - can be characterized as extremely complex, interdependent, high stakes issues. In response to these issues, a relatively new field of scholarship on wicked problems calls for engaged scholarship, a collaborative and integrative educational model, and more transparent and participatory democratic engagement. In contrast to "tame" problems - problems easily defined and solved one-dimensionally - wicked problems are categorized within the literature as dynamically

Food Studies: An Interdisciplinary Journal

Volume 5, Issue 1, 2015, www.food-studies.com, ISSN 2160-1933

(C) Common Ground, Anne Marie Fauvel, Danielle Lake, All Rights Reserved

Permissions: cg-support@commongroundpublishing.com 
complex and ill-structured, with no straight-forward causal chains to help us gain a clear and simple picture of the issue. ${ }^{1}$ They are in some sense obstinate and indefinable, influenced by many dynamic and complex factors (Brown 2010,4). They consistently confront us with high levels of uncertainty in situations where both action and inaction carry high-stakes. These problems, then, are not amenable to final resolutions and cannot successfully be ignored.

In fact, Valerie A. Brown, Peter M. Deane, John A. Harris, and Jacqueline Y. Russell (2010) reminds us that supposed "miracle solutions" to some of our most troubling environmental problems have instead consistently led to unintended consequences. We can, for example, easily point to the dangerous problems we are now facing from intensive agriculture like soil erosion, pollution, desertification, and health problems related to pesticide use. Especially challenging, wicked problems "require solutions that challenge the current practices of the society that generated them" (6). On the whole, the burgeoning literature on wicked problems makes fruitful distinctions between itself and complex problems, highlighting more intense disagreement between fragmented stakeholders, multiple and often conflicting objectives, as well as higher levels of uncertainty, variability, and risk (Salwasser 2004, 12).

However, the current, dominant educational model adds to our difficulties. This is largely because it separates and isolates interested stakeholders, encouraging divergent interests and values, different understandings of risk, and conflicting end-goals (Salwasser 2004, 9). Such structural fragmentation - on top of a competitive and aggressive, interest-driven, zero-sum political climate - makes comprehensive, collaborative long-term responses difficult. In contrast, the wicked problems (WP) approach to our food crises has the potential to redirect attention so students can better see these complex, high stakes problems in a more comprehensive light.

\section{Wicked Food Issues}

Food quickly and decidedly qualifies as a wicked issue worth tackling. The way we eat, for instance, has serious consequences for our health and thus for many of the problems we face within our healthcare system. Much of our current health troubles, such as type 2 diabetes, heart disease, and cancer, stem largely from our diet. It is no secret that global obesity rates are on the rise. ${ }^{2}$ If healthy life-long habits do not take root in our formative years, the data indicates serious issues for future populations. ${ }^{3}$ Furthermore, obesity has been linked to socio-economic status in both adults and children. ${ }^{4}$ On the other hand, new evidence points to a slight decrease in obesity rates in the United States for the past decade. ${ }^{5}$ This decrease is likely attributed to the nutrition guidelines mandated in schools (Schultz 2013). More recent studies by Peter Hinrichs indicate that the U.S. National School Lunch Program - shaped and reshaped since 1946 - helps to educate children with less behavioral management issues but still fails to give them life-long healthy eating habits (Hinrichs 2010). Even if the school lunch program was successful in the face of many challenges, it alone fails to address a wider contextual problem in our homes, stores, and restaurants. Alkon et al. point to food deserts, i.e. neighborhoods lacking access to healthy foods, as the primary reason for the diet-related health issues (2013). Alternately, the same authors concluded that cost, not the lack of knowledge or physical distance, is a primary obstacle in gaining access to healthy food (Alkon et al. 2013). Ever-widening contributing factors

\footnotetext{
${ }^{1}$ The term was widely disseminated through a 1973 article on city planning by Horst Rittel and Melvin Webber, but has more recently taken root in a wider array of literature on the environment.

${ }^{2}$ In fact, the Centers For Disease Control in the United States declared that $35.9 \%$ of the population 20 years or older is considered obese (CDC, 2013).

${ }^{3} 18.4 \%$ of the population age $12-19,18.0 \%$ of children $6-11$ years of age and $12.1 \%$ in children between $2-5$ years old are found obese (CDC, 2013).

${ }^{4}$ Ogden et al. noted that 'among both boys and girls obesity prevalence decreases as income increases, but this relation is not consistent across race and ethnicity groups' (2010).

${ }^{5}$ Centers for Disease Control and Prevention also released data early last year showing that from 2003 through 2010 the prevalence of obesity decreased by $0.27 \%$ among low-income preschool children.
} 
can be pointed out, but given the limits of time and space we provide only a few more reasons food issues qualify as wicked.

Health, education, the economy and politics are - in effect - just the beginning. Michael Pollan, in an open letter to the President-Elect in 2008, goes on to enumerate the multifactorial effects of our "agricultural policies in shambles." He highlights climate change, compounded by our heavy dependence on cheap fossil fuels and the rising health care crisis created by a food system extremely efficient at growing corn and the use of all of its by-products (Pollan 2008). In addition, wide-spread global interdependencies (and thus power struggles) can be seen through examining the dominant food systems in operation today. Growing, packaging, transporting, distributing, marketing, accessing and consuming the food, to name only the obvious, must be reexamined. "There are," Pollan notes, "no alternatives to food." He, in fact, makes it quickly apparent that the history of U.S. policy has drastically shaped and reshaped the landscape of our food system. Important for the development of the course described below, he argues we need a willingness to learn-by-doing in order to foster wide-spread change (Pollan, 2008 8). At the heart of many current societal and political debates, food clearly presents a broad spectrum of high stakes, complex, interdependent problems; that is, food qualifies as a wicked problem.

\section{Course Design: Bottom-Up Collaboration and Integration}

"Wicked Problems of Sustainability" was designed to fit in a revitalized general education program at Grand Valley State University. The intent is to provide upper-division undergraduate students with a hands-on, collaborative experience at working on a local wicked problem of sustainability with community partners. Given that West Michigan is rapidly becoming a hub for sustainable development with active food communities at the heart of it, this first course took on issues within the food system. During a local food summit, the semester-long WP focus question was developed from multiple prospective disciplinary stakeholders: "How can we put healthy food in the hands of school children and instill life-long healthy eating habits?" The content and skill objectives for the course asked students to:

1. Identify and apply the literature on wicked problems to food, food systems, and food communities;

2. Research and analyze case studies via two or more different disciplinary lenses with a goal towards integration;

3. In collaboration, present findings and facilitate deliberation on possible action plans;

4. Analyze deliberative conclusions and propose solution or action effort, communicating the results of the project to the community.

Given these objectives, course readings this first semester covered issues in environmental philosophy, systems thinking, wicked problems, transdisciplinarity, sustainability, applied economics and politics, team processes, democratic deliberation, water policy, food justice, and citizen-scientists, among others. ${ }^{6}$ As an interdisciplinary, upper-division, general education course focusing on collaboration, integration, and problem-solving, there is the hope that a diverse group of majors enroll in order to foster cross-disciplinary work that addresses multiple

\footnotetext{
${ }^{6}$ Students read the work of scholars like Valerie Brown, Frank Fischer, Sandra Batie, David Freeman, Kristin ShraderFrechette, Daniel Kleinman, and Bryan Norton, among others.
} 
food facets. Such a goal aligns with the best practices for transdisciplinary sustainability science. ${ }^{7}$ This first course generally succeeded on this front. ${ }^{8}$

The course began with student presentations on their own disciplinary knowledge in relation to food issues. After these presentations, students self-selected interdisciplinary teams of threeto-five and began the semester-long collaborative process of (1) defining (and redefining) the wicked food issue they were tasked with, ${ }^{9}$ (2) creating, vetting, and revising action plans, then (3) presenting their work to the stakeholders involved and (4) reviewing and incorporating stakeholder suggestions. This process generally follows the recommendations found within the Wicked Problems scholarship where efforts to meliorate these problems begin through careful and inclusive issue framing, the consideration of a wide range of objectives and values, the weighing of creative action options, and - ultimately - the decision to implement action on-theground with a community partner. ${ }^{10}$ Since the global food system engages a number of highstakes interlocking systems (economic, ecological, political, social, etc.) and thus presents a series of robust challenges for students, various stakeholders and experts were invited to share their insights. ${ }^{11}$ By engaging through a bottom-up methodology, this process avoided a common critique of some participatory action research efforts when community-involvement occurs too late in the process. By collaboratively framing the issue-at-hand from the beginning, the chances for cooptation and implicit exclusion diminish. In general, including as wide an array of stakeholders as possible discourages the temptation towards unproductive finger-pointing and thus helps to reroute the framing of problems so that initially competitive and authoritative problem-definitions become more inclusive and holistic. These efforts were meant to help democratize the proposal process. Towards the end of the semester, a food-focused community dialogue event was created to facilitate the presentation of student proposals. At this event formal feedback was solicited and then integrated into students' final set of recommendations. In the end, student proposals were published through GVSU's ScholarWorks website so they could be made available not only to future students in the course, but also a wider array of potential interested parties.

Unlike similar courses asking students to create and implement community-action plans, this course encourages current students of the course to read, critique, revise and implement aspects of previous students' work. The potential to build on earlier work in subsequent semesters counter-acts problems arising from artificial timelines and semesterly attrition. Scaffolding student-efforts so they stretch beyond fifteen week projects is imperative when trying to empower long term positive change within the community. In contrast to the current most

\footnotetext{
${ }^{7}$ The research shows that TDSS work requires the integration of knowledge and skills from a wide array of disciplines and communities (Spangenberg 2011).

${ }^{8}$ For example, the twelve students in the first run of the course came from a variety of majors, including Environmental Studies, Natural Resource Management, Psychology, Journalism, Education, Legal Studies, as well as a number from Liberal Studies (a student-designed interdisciplinary major encouraging unique specializations), and one with an emphasis in business. This first cohort included returning-adult students and traditional-age college students, but was less diverse across race and socio-economic status.

${ }^{9}$ The particular wicked problem students are tasked with can vary from semester-to-semester and instructor-to-instructor depending on local concerns, instructor expertise, and community partnerships. While the instructor may initially frame an issue for students to address, it must be framed broadly, allowing student-teams and community partners to direct action-efforts as they see fit. For instance, detailed later, students this first semester engaged issues surrounding local school-age children and food. Student team proposals ranged from after-school clubs, to community events engaging children, to the design and implementation of an interactive website aimed at empowering kids to eat healthy and local foods.

${ }^{10}$ Efforts to address these problems cannot, according to Gerald M. Allen and Ernest M. Gould, "be standardized" (1986 23). There are a variety of similar models and methods for this work from Transdisciplinary Sustainability Science (TDSS), to Transformational Learning for Collaborative Change, Participatory Action Research, to Soft Systems Thinking, and Strategic Doing.

${ }^{11}$ These stakeholders included a food service director for a local school system, the director of GVSU's Charter Schools' Office, GVSU's sustainable agriculture manager, the former sustainability community liaison for West Michigan Strategic Alliance (a "Creativity Consultant" and Environmental Advocate), among a long list of others.
} 
popular educational model where problems are pre-formed and students are simply asked to solve them, students - in conjunction with instructors and stakeholders - spend much of the semester framing the food problem they were addressing. This constructivist approach to problem-building is quite difficult, time-consuming, and unavoidably messy. As we will see, it requires much from the students.

\section{Results}

On Valerie Brown and Judith Lambert's engagement rubric (2013), students were asked to engage key individuals, specialist advisors, influential organizations, holistic thinkers and affected communities. Noting barriers from a lack-of-response to initial requests, students found it quite hard to engage key individuals and affected communities. In general, though, engaging with a diverse group of interested stakeholders encouraged perspective-taking beyond their own, leading to a more comprehensive understanding of the situation. For instance, student final proposals consistently noted how various stakeholders and experts influenced their project plan recommendations (detailed below). These stakeholders definitely tended to make "blockages visible and thus areas for co-action visible" (Van Bueran et al. 2003, 211).

On the other hand, the feedback loop process also led to stress and anxiety over how to address the problem-situation. Continuously returning to project plans and redirecting them was a source of frustration for students as it was incredibly difficult to address the situation when project plans were undergoing a long process of critique and revision. Students were engaged in truly "messy inquiry" (Alpaslan and Mitroff 2013, 127), and quite unused to working in this way given the current dominant educational structures, they found it exceedingly challenging. Based on student commentary and written feedback, it seems doubtful they found many opportunities to appreciate conflict and complexity while in the process, though - with consistent encouragement - they certainly worked to tolerate and engage conflict and complexity (Brown and Lambert 2013, 133). ${ }^{12}$ Thus, as Brian Norton suggests, students moved from the reflective to the active phase and back-again in a frustration-inducing, iterative semester-long process: a process which did ultimately lead to project proposals $(2005,143)$.

\section{Project Proposals}

The Team Project Proposals required students to provide background information about the particular wicked problem they confronted and thereby orient readers to the issue. All three student teams were given some power and freedom to collaboratively direct their efforts in a way they found fruitful. The Project Proposals also asked students to clearly articulate their research question along with its components, justify the research fields used to work on the problem, and integrate the perspectives engaged. In the end, the plans also described the methods used, generated a timeline for action, and considered a list of future collaborators. In order to provide the reader with a general idea of the insights and outcomes generated from these requirements (and adhere to the limitations of space), two of the team project proposals are sketched in brief below.

The "Food Maverick" student team, after confronting consistent barriers in their attempts to reach out to local stakeholders about their current school lunch program - including principals, teachers, and administrators - quickly recognized the role and value of localized resistance (Shrader-Frachette 2002). In fact, hoping to inspire this resistance, they ultimately decided to create FoodMavericks.org, a website designed to speak to and with school age children. In their words, this site is intended "to reach children where they already are... on the web" (Karnatz et

\footnotetext{
${ }^{12}$ As Brian McCormack makes plain in "The Problem with Problem Solving," the constructivist approach to problem formulation forces students to confront their own relationship to the issue and thus some of the here-to-fore unconscious complexities and ambiguities inherent in their own identities (McCormack, 2009).
} 
al. 2014, 1). Considering their ultimate goal, their values, and their skill sets, the Food Mavericks noted that their focus was on "giving kids a voice, spreading good ideas, and having fun!" Their aim, just as their name suggests, was to encourage adolescents to think for themselves.

Given the above, it is no surprise that this group focused on issues of power in relation to food justice, asking how they can "empower children to make choices which best promote a long and healthy life" (Karnatz et al. 2014, 3). In their frustration over failed efforts to reach out to various organizations, they decided to try to create a movement from the bottom-up by empowering kids to see through the thousands of food advertisements they are exposed to every day. ${ }^{13}$ Their final plan was to "create an edgy, viral campaign to promote healthy foods" by "utilizing a combination of blogging, videos, recipes, and guerilla marketing stunts." This led to the creation of their website encouraging healthy eating and a more critical eye towards advertising in general (Karnatz et al. 2014, 6). Foodmaverick.org seeks to aggregate material from other sites, more intentionally entertain through education, and create an avenue for kids to have a voice (Karnatz et al. 2014, 6). ${ }^{14}$

While the group successfully implemented a significant portion of their action-plan by creating the website, they also highlighted serious concerns about the sustainability of their plan and the difficulties of this kind of work. Given the workload commitment necessary for maintaining a website and successfully marketing it, they were uncertain about its future viability (successful websites often requires a dedicated team). For example, marketing the site is likely to require concerted efforts toward partnering with schools, businesses and organizations, as well as creating a presence at local events. Noting other special challenges in their proposal process, the team wrote that they struggled with (1) the fact that these issues cannot be quickly resolved, (2) the need to continuously collaborate with the food community, and (3) keeping the big picture in mind (Karnatz et al. 2014, 8). In considering the work necessary for the future the group suggested it would be helpful to collaborate with other majors, partner with other agencies in order to defray the cost of marketing and branding the site, include local school districts in vetting and implementing the site, and connect with (advertise at) local events and organizations (Karnatz et al. 2014, 9-10).

The second student group, "Fresh Start Day Club," began by considering their values and goals as a team; after considering their own assets and networks, they proposed implementing an after school club focused on teaching local school children how to produce, preserve, and prepare food. Particularly interesting about this student group proposal is its local appeal. They decided to route this program through their own community, concerned about putting their theories into action in a way that was directly connected to their own experiences. Moreover, by beginning their work with the integration of group interests and values, they hit upon one of the most highly valued aspects of WP scholars Brown and Lambert's suggested process for collaboration on wicked problems (2013).

Fittingly, then, the Fresh Start Day Club's foci were children, nutrition, education, and sustainability (Bell et al. 2014, 3). The club they envisioned was designed to meet the group's core goals: "to educate, inspire, promote, and excite children... towards healthier and sustainable lifestyles" (Bell et al. 2014, 4). The team posited school-age children would learn about organic farming, greenhouses, and hoop houses. Children could, for instance, tour GVSU's Sustainable Agriculture Project (SAP), engage in taste tests of fresh versus processed foods, prepare simple meals, create and take home recipe cards with local chefs, plant seeds with recycled materials, and help create how-to pamphlets. Behind the suggestions given in their final proposal, they note

\footnotetext{
${ }^{13}$ In considering how to empower school-age children to take more ownership over their food choices they moved from ideas over creating guerilla advertising opportunities in schools, to field trips to farmer markets, to food tastings, to largescale events, to the creation of a website targeted toward adolescents (Karnatz et al. 2014, 5).

${ }^{14}$ The site will "include videos and content created by Foodmaverick.org," "aggregate videos, news and information from across the web," "share recipes that are fun and healthy," "include coverage of guerilla marketing stunts," allow kids to submit content of their own, generally "serve as a hub-point for social media," include a parent resource tab, and help to brand Food Maverick (Karnatz et al. 2014, 7).
} 
two central goals: (1) to give children a sense of ownership over the program and (2) to get children to learn-by-doing (Bell et al. 2014, 10). Seeing the value of celebration and community, the proposal suggests the club culminate in a Community Day where friends and family come to see their children lead various activities and receive a certificate of achievement. ${ }^{15}$

In the end, student groups' collaborative efforts to work with interested parties was critical to the quality, creativity, and viability of their final proposals. ${ }^{16}$

\section{Final Dialogue Event}

The final dialogue event sought to bring together as many interested stakeholders and food community members from across West Michigan as it could with the intent of exposing individuals and organizations to students' work, eliciting feedback, and creating food networking opportunities. This event began by introducing attendees to wicked problems broadly and then briefly explained how food issues are wicked. Each student-team gave a twenty minute presentation of their proposals, followed by discussion with attendees. In the end, ample time was also provided for one-on-one discussions.

The final event was intentionally designed with - and widely supported by - the wicked problem scholarship. For instance, the wicked problem scholarship consistently recommends working across networks. Believing that creating opportunities for this to happen is crucial to the success of future collaborative endeavors, students were asked to recruit attendees from a widearray of backgrounds. Supporting the conclusion that providing the space and opportunity for cross-network collaboration is critical to building opportunities, event attendees consistently volunteered to help move project proposals forward. ${ }^{17}$ Event evaluations were also designed with the aim of eliciting feedback and fostering collaborative partnerships. ${ }^{18}$ Aware of the limits of deliberation both within large groups and under time constraints, the evaluations asked attendees to indicate how they might want to get involved and what they (or we) may need in order to move the action-plans towards implementation. Responses were overwhelmingly positive. In general, the event was seen as a success by the students, instructors, and attendees. Serious outreach efforts resulted in a breadth of diverse stakeholders and active food community members. ${ }^{19}$ The event demonstrated that generating perplexity in order to foster cooperation is indeed quite valuable.

\footnotetext{
${ }^{15}$ Like the Food Mavericks, this group began their work by seeking advice from local school administrators; they emailed teachers, administrators, and lunch staff, but also received a lack luster response. By regrouping and considering their own networks, they successfully sought out a local nutritionist and dietician, the executive Director of Sustainable Community Development Initiative at GVSU, as well as GVSU's Sustainable Agriculture Project (SAP) manager for advice and received both strong support and a healthy list of suggestions.

${ }^{16}$ The third student group, C.A.R.R.O.T/G.A.R.D.E.N.S, focused on the role parents' play in shaping their children's food preferences and for this reason chose to focus on the family and community as a whole. Considering their own interests and values, they created their team name, which stands for Communities About Resource Responsibility of Tomorrow, Growing A Resource Dense Environment In Schools. They argued reaching out to current and future parents could help prevent unhealthy eating habits from developing by fostering healthier home environments. Noting the prevalence of school and community gardens, they decided to create blue prints for a larger community event by creating mini-travel booths focused on educating farmer's market attendees on how to grow a garden, save seeds, harvest, can and juice. In the end, given team struggles to define the target group and frame the issue, this project proposal is not as detailed and directive as the first two (leaving more room for future students to shape the direction of these initial suggestions).

${ }^{17}$ For example, a professor in attendance offered to let current and/or future students pitch project proposals to his students (with the intent that his students may want to implement various aspects of the plan as a part of their own course work). The president of GVSU's Student Environmental Coalition offered to help drive volunteer efforts and GVSU's Sustainable Agriculture Project (SAP) manager agreed to help design and educate future K-12 student clubs about healthy and local foods.

${ }^{18}$ Evaluations, for instance, asked attendees' questions like, "What insights do you want to contribute towards the revisioning of project plans?"

${ }_{19}$ Approximately thirty-five people attended the event, including GVSU's director for Community Engagement and Sustainable Agriculture Project Manager, Grand Valley students, an associate dean, a handful of professors, family
} 
As the literature suggests, engagement models can and often do encourage creativity. The breadth of student project-plans demonstrates that such engagement models can certainly lead to more viable and creative action-plans. Stakeholder engagement encouraged an iterative, creative process and hence also encouraged flexibility. Given that wicked problem scholars highlight the need for flexibility - for resiliency - in the face of our current and future crises, fostering these skills now should prove valuable to students' future work. Completely unplanned, the three student groups ended-up developing food related projects focused (1) in the school, (2) on the web, and (3) in the community. Intentionally pursuing these different venues with an eye towards how they can reinforce one another in future courses should further drive effective change. Students provided the space for an interdisciplinary dialogue which in turn encouraged the strengthening of a budding local food community, empowering change.

\section{Future Considerations}

In general, the final dialogue event led to a number of further recommendations for future student-efforts. For instance, while there is often a great deal of buzz around initiating change, the difficulty comes in sustaining real, long-term change. On this front, teams should intentionally seek out those who have done this work for an extended time and ask for advice. The depth of knowledge left unmined from, for instance, local farmers, food procurers, cold storage experts (among a long list of others) would add a richness to any of the proposal projects. The addition of such experts is also likely to encourage more realistic and helpful outcomes of student action-efforts. Along these lines, attendees also suggested teams do more to seek out those with assets to contribute beyond expertise. ${ }^{20}$

In considering the depth and breadth of participation across sectors (Turnpenny et al. 2009, 347-358), students could have and will need to do more to invite a wider-range of perspectives into framing the food issue and vetting the project-plan. As Jane Addams noted long ago, work on public problems needs to be done with those affected, not to them. In failing to more systematically engage primary school students, these proposals cannot engage local children's concerns, nor "move along with" them to create effective change (Addams, 2002, 69). As team projects undergo future revision and implementation within the community, there will be a more intentional focus on this element of the course. ${ }^{21}$ In addition, more work explicitly reflecting on the dynamics of power within the food system would go a long way towards recognition of system dynamics and thus towards effective student work. Highlighted briefly above, the Food Mavericks group was concerned that efforts to force "healthy foods" into school lunches had resulted in a large amount of food-waste (Karnatz et al. 2014, 2). While their project proposal their website and future action plan - was built on the foundational principle of engaging children directly, they didn't systematically pursue this objective before the end of the semester. On this front, future students should do more to engage local children in the re-visioning of plan proposals. Despite the obviousness of working to engage children directly, student teams appeared to make only rudimentary efforts to do so. Their initial research efforts at first seemed to inspire the idea that they knew what was better for the children. Future students will thus be required to explicitly engage with their targeted communities before implementing any actionplan.

On the other hand, one semester of this work illustrated just how troublesome getting stakeholders to the table really is (as all the students noted). Trying to work across power

members, local non-profit leaders, and a local middle school student. Building on this first outreach effort will help to ensure a greater diversity of attendees in future deliberative events. For example, some stakeholders - like a local charity house and GVSU's food pantry - previously not consulted wanted to be in the future.

${ }^{20}$ People who need volunteer hours, who have resources to donate should be engaged in this work. In general, students should pursue communities of interested people.

${ }^{21}$ While reciprocity between outside stakeholders and students was not very apparent, some stakeholders did note the value they received from engaging students on their work and their interest in staying involved in future student efforts. 
differentials and networks in our current system, given the dominance of a competitive and authoritative model, is incredibly challenging and time-consuming. On top of this, various stakeholders admitted they were worried about how they would be portrayed if they agreed to openly share their internal processes with us. Wicked problem scholars clearly note these types of problems: stakeholders seeking to advance their own self-interest and deeply distrustful of others make collaborative engagement efforts exceedingly difficult (Van Bueran 2003, 207). Thus, tenacity and flexibility are necessary.

On top of these concerns, the iterative process of defining the problem and arriving at a planof-action makes moving students to action in one semester incredibly difficult. ${ }^{22}$ Balancing a comprehensive systems approach, where most relevant disciplines and stakeholder perspectives are included in the planning process, with the need to - at some point - stop planning and start doing is a challenging and nuanced endeavor. It thus proved to be a bit too ambitious to expect the creation, re-visioning, and implementation of project plans in one fifteen-week semester. Supporting this conclusion, systems thinking research demonstrates that acquiring the skills of this kind of work usually requires more than a fifteen-week commitment (Mathews and Jones 2008,82 ). We also argue that the need to shift our thinking towards collaboration, iteration, and fallibilism - to foster these skills sets and develop these habits - is more critical for our students today than is the need to memorize particular content within an artificial timeframe.

Thus, mastering thinking and working in this way cannot happen in one semester, especially given how counter-intuitive it is for students who have been trained in the current U.S. educational system. Students' final reflections verified this. For instance, one student wrote that "even though we knew the philosophy behind wicked problems, it took tackling one ourselves to really understand the magnitude of such issues." Expressing a like-minded point, yet another student wrote about how humbled she was by the work of this course, noting that "all this humbling was just the beginning catalyst... It inspired me to look beyond my own beliefs and values." Perhaps counterintuitively, a different student noted a greater optimism coming out of her work in the course, saying "before taking this class, I believed that I could never personally make a difference on such large scale problems. After taking this class, I understand that it is the little actions from people in the communities that make the difference." Aligning with WP recommendations, this insight on the requirement for incremental action, combined with the insight on the value in failure, demonstrate noteworthy transformations in student thinking. Considering the great difficulties students had in collaborating on these problems and engaging stakeholders, more explicitly implementing facilitative materials intended to help teams arrive at and implement action plans should prove fruitful in future semesters. ${ }^{23}$ These materials could range from democratic deliberative process suggestions, to facilitation tools, to systems mapping, to Strategic Doing ${ }^{24}$ strategies. More direct aid on this front should also reinforce what students found of most value: the skill sets engendered by this type of work.

The final dialogue event created an effective, though temporary boundary space by inviting different food perspectives into the dialogue, holding students accountable to the organizations involved, vetting their ideas and co-generating creative insights on how to best address the local food issues more comprehensively. In addition, by requiring students to publish their revised project proposals through GVSU's ScholarWorks, students are taking steps to communicate their "knowledge" more broadly and are thus bridging boundaries here as well. For instance, subsequent "Wicked Problems of Sustainability" students are required to read previously published team proposals; they then have the option to revise and implement aspects of this

\footnotetext{
${ }^{22}$ Indeed, one student reflecting at the end of the semester, wrote that this type of collaboration, when "trying to come up with something effective, all while under a deadline, is a terrifying and brutal experience." Following this assertion up by noting this type of work is also "extraordinarily effective at educating us on just how complicated and difficult Wicked Problems are."

${ }^{23}$ One student explicitly called for more collaborative training and support in his final evaluations: asking for more focus on teamwork and more time to "dive right in" to the process.

${ }^{24} \mathrm{See}$ http://insight-cced.strategy-nets.net for further details.
} 
initial work. Thus, this course tries to intentionally link knowledge-production to knowledge-use across time and distance. Also as recommended by bridge building work, the course employs a research strategy that is "open to changes in attitudes and open in outlook toward cooperation and negotiation" (Gross 2009, 92). Ultimately, then, we believe this course provides the space, opportunity, and several "incentives" to do this kind of work (Guston 2001, 17-34). In effect, it operates as a bridge, bringing people together to tackle wicked food issues in our local community. The course begins to incentivize collaborative efforts to address shared food problems by building it into course expectations.

\section{Conclusion}

In no way does this course allow students to philosophize in isolation (Seigfried 1996, 98). Quite interesting about the creation and implementation of this course is how strongly its goals align with the recommendations from not only the WP scholarship and the pragmatic method, but also with the American Academy of Colleges and Universities suggestions and the recommendations from the scholarship on effective teaching and learning in today's world. This research shows collaborative, experiential learning processes - like those employed here - are far more likely to result in essential skill sets for students' lives ahead. Clearly, then, our educational systems should require students to work collaboratively on real, complex, public problems.

This course is one small step in the right direction. It moves us in a fruitful direction because (1) it gives students not just a depth of knowledge within a particular field (in this case food and its many related issues), but also encourages breadth by building assignments which require students to look outside their expertise and integrate; (2) it empowers students to learn the skillsets of true collaboration; (3) it encourages students to recognize the value of not just reflection, but also action and hence the importance of an iterative process; and (4) it thus exposes them to and asks them to actively engage in - deliberative processes (as the final dialogue event did) on critical complex issues such as the future of food systems. The course asks students not only to make efforts towards tackling our collective food problems, but to first define them comprehensively and collaboratively, to hypothesize possible ameliorative action-plans, to call on stakeholders (i.e., develop food communities) and to honestly weigh these plans against alternatives.

In line with John Dewey's educational philosophy, this course demonstrates that experiential learning can and does foster adaptation. As he noted long ago, this work requires a certain amount of vitality and courage (Dewey 1983, 163); and students definitely had to dig deep for both. The incredible challenge and value of this work also highlights the deep need for boundary organizations (for bridge institutions). Creating change by working with others goes against the dominate strain; it's a slow and painful, often unsatisfying process and it is absolutely vital to our survival ahead. Transformation, however, is the result of such work.

It is clear that effectively engaging wicked food problems requires more than expertise can give since expertise in a particular field does not train one to engage in intractable uncertainties nor in conflicts of value. Thomas Homer-Dixon (2013) suggests these problems require we ask ourselves what "the good life" really consists of. He argues we must be more cognizant of our core beliefs, values, and motivations and recognize that we all have a role to play. Indeed, Homer-Dixon notes that our collective intelligence leaves quite a bit to be desired; he fittingly compares the collective intelligence of all 6.2 billion people on this planet today to that of bacteria in a petri dish, mindlessly consuming everything in sight. Homer-Dixon goes on to suggest we must move from a stage of species "adolescents" to a stage of wisdom; that is, it's time to grow up (Homer-Dixon, interview). In the end, we only wish to make the modest assertion that this course begins the work and fosters the values and skills essential to tackling the wicked problems we face ahead; food issues being at the top of the list. 


\section{REFERENCES}

Addams, Jane. 2002. Democracy and Social Ethics. Chicago, IL: University of Illinois Press.

Allen, Gerald M. and Ernest M. Gould. 1986. "Complexity, Wickedness and Public Forests." Journal of Forestry. 84, no. 4: 20-24.

Batie, Sandra. 2008. "Wicked Problems in Applied Economics." American Journal of Agricultural Economics. 90, no. 5: 1176-1191.

Bell, Evan, Ross Damon, Dana Eardley and Jessica Siemen. 2014. "Fresh Start: Inspiring our youth with knowledge, experience, access to farming, local foods, and life skills for healthy and sustainable living." Accessed January 18, 2014. http://scholarworks. gvsu.edu/wickedproblems/1/

Brown, Valerie A. and Judith A. Lambert. 2013. Collective Learning for Transformational Change: A Guide to Collaborative Action. Routledge: New York.

Brown, Valerie A., Peter M. Deane, John A. Harris, and Jacqueline Y. Russell. 2010. "Collective Inquiry and its Wicked Problems." In Tackling Wicked Problems through the Transdisciplinary Imagination, edited by Valerie A. Brown, John A. Harris, and Jacqueline Y. Russell, 61-83. London; Washington, DC: Earthscan: 61-83.

Campbell, Joel, Jessica Dake, Breanna Dubanik, and Marisha Ibrahim. 2014. Communities About Resource Responsibility Of Tomorrow: Growing A Resource Dense Environment In Schools. Accessed January 18, 2014. http://scholarworks. gvsu.edu/wickedproblems/3/

Center for Disease Control and Prevention. 2013. National Center for Health Statistics. Accessed January 15, 2014: http://www.cdc.gov/nchs/fastats/overwt.htm

Dewey, John. 1983. Human Nature and Conduct. The Middle Works, 1899-1924, Vol. 14. Ed. Jo Ann Boydston. Carbondale: Southern Illinois UP.

Fischer, Marilyn. 2011. "Interpretation's Contrapuntal Pathways: Addams and the Averbuch Affair." Transactions of the Charles S. Peirce Society. 47, no. 4: 482-506.

Fischer, Marilyn. 2004. On Addams. Louiseville: Thomas Wadsworth.

Gross, Matthias March, 2009. "Collaborative experiments: Jane Addams, Hull House and experimental social work.” Social Science Information. 48, no. 1: 81-95.

Guston, David H. 2001. "Boundary Organizations in Environmental Policy and Science: An Introduction." Science, Technology, and Human Values. 26, no. 4: 399-408.

Hinrichs, P. (2010). "The Effects of the National School Lunch Program on Education and Health." Journal of Policy Analysis and Management. 29: 479-505. Accessed January 18, 2014. doi: 10.1002/pam.20506

Homer-Dixon, Thomas. Wicked Problems Interview. Ecoshock Radio: Awareness, Action, and Transition. Alex Smith. Accessed December 20, 2013. http://www.ecoshock.info/ 2011/03/wicked-problemssolutions.html

Karnatz, Hilary, Christina Ober, Alison Sells, and Carlton Sumner. 2014. The Food Mavericks Project. Accessed January 18, 2014. http://scholarworks.gvsu.edu/wickedproblems/2/

Kolb, David. 2003. Experiential Learning: Experience as the Source of Learning and Development. Upper Saddle River, NJ Prentice Hall.

Mathews, Leah Greden and Andrew Jones. 2008. "Using Systems Thinking to Improve Interdisciplinary Outcomes." Issues in Integrative Studies 26: 73-104.

McCormack, Brian. 2009. "The Problem with Problem Solving." Issues in Integrative Studies 27: 17-34.

Norton, Bryan G. 2005. Sustainability: A Philosophy of Adaptive Ecosystem Management. Chicago: University of Chicago Press.

Ogden CL, Lamb MM, Carroll MD, Flegal, KM. 2010. Obesity and socioeconomic status in children: United States 1988-1994 and 2005-2008. NCHS data brief no 51. Hyattsville, MD: National Center for Health Statistics: 1-8. 
Pollan, Michael, 2008. "Farmer in Chief." New York Times, October 9, 2008. http://ice.as.arizona.edu/ fozel/Site/Phys202lectures_files/Farmer\%20in\%20Chief.pdf

"Problem Solving Value Rubric." Association of American Colleges and Universities. Accessed January 4, 2014. http://www.aacu.org/value/rubrics/pdf/ProblemSolving.pdf

Seigfried, Charlene Haddock. 1996. Pragmatism and Feminism: Reweaving the Social Fabric. Chicago: University of Chicago Press.

Shrader-Frechette, Kristin. 1991. Risk and Rationality: Philosophical Foundations for Populist Reforms. Los Angeles: University of California Press.

Schultz, E. J. 2013. "OBESITY RATES: The nation's obesity epidemic is only getting worse, or is it?" Advertising Age 84, no. 13: 20. Retrieved from http://search.proquest.com. ezproxy.gvsu.edu/docview/1323542735?accountid=39473

"Teamwork Value Rubric." Association of American Colleges and Universities. Accessed January 4, 2014. http://www.aacu.org/value/rubrics/pdf/teamwork.pdf

Turnpenny, John, Irene Lorenzoni, and Mavis Jones. 2009. "Noisy and Definitely Not Normal: Responding to Wicked Issues in the Environment, Energy and Health." Environmental Science \& Policy 12: 347-358.

Van Bueren, Ellen M., Erik-Hans Klijn, and Joop F. M. Koppenjan. 2003. Dealing with Wicked Problems in Networks: Analyzing an Environmental Debate from a Network Perspective. Journal of Public Administration Research and Theory 13, no. 2: 193-212.

\section{ABOUT THE AUTHORS}

Danielle Lake: Affiliate Professor, Liberal Studies Department, Grand Valley State University, Allendale, Michigan, USA.

Anne Marie Fauvel: Affiliate Professor, Liberal Studies and Biology Departments, Grand Valley State University, Allendale, Michigan, USA. 
Food Studies: An Interdisciplinary Journal explores new possibilities for sustainable food production and human nutrition. It provides an interdisciplinary forum for the discussion of agricultural, environmental, nutritional, health, social, economic and cultural perspectives on food. Articles range from broad theoretical and global policy explorations, to detailed studies of specific humanphysiological, nutritional and social dynamics of food. The journal examines the dimensions of a "new green revolution" that will meet our human needs in a more effective, equitable and sustainable way in the twentyfirst century.

As well as papers of a traditional scholarly type, this journal invites case studies that take the form of presentations of practice-including documentation of socially-engaged practices and exegeses analyzing the effects of those practices.

Food Studies: An Interdisciplinary Journal is a peerreviewed scholarly journal.

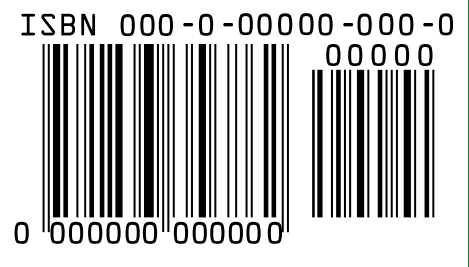

